УДК: 327:616-036.21

DOI: https://doi.org/10.18485/fb_covid19.2020.ch2

\title{
ПОЛИТИКОЛОШКА АНАЛИЗА РАЗЛИЧИТИХ ОДГОВОРА НА ПАНДЕМИЈУ КОВИДА 19
}

\author{
проф др. Мирослав Младеновић 1 \\ др Сергеј Григорјевич Мусијенко²
}

Сажетак: Глобални проблем о коме читамо у књигама научне фантастике постао је стварност. Чини се да су бројна уметничка остварења и филмови на ову тему постали или пророчки или су послужили као упутство за практично деловање. Оно што се појавило у стварности и њене последице могу да надмаше фикцију. Информативни утицај инспирисан заразним болестима без преседана је у свету. Глобални безбедносни проблем је очигледан. Упркос пандемији коју је објавила Светска здравствена организација (С30), ниједан оружани сукоб у свету није заустављен. Испоставило се да „главни командант Светских снага за брзо реаговање“ - СЗО у великој мери није спреман, као и велика већина земаља света. Тактика борбе и супротстављање пандемији мењају се у кратким временским размацима и из државе у државу, уз сталне оптужбе и претензије једних према другима. Многи светски лидери показали су се као лидери у некомпетентности. Још увек није разјашњено одакле је тачно почела дистрибуција ковида 19 , као и његово стварно порекло. У раду ћемо настојати да извршимо политиколошку анализу функционисања држава у условима претњи њиховим безбедносним системима, упоређујући земље које су увеле строге пандемијске и карантинске мере и алтернативно понашање Белорусије и Шведске.

Кључне речи: ковид 19, пандемија, СЈИ, Белорусија, СЗО, политичке промене.

\footnotetext{
1 Универзитет у Београду, Факултет безбедности; e-mail: m.mladenovic@fb.bg.ac.rs

Чланак је резултат рада на пројекту Министарства просвете, науке и технолошког развоја Републике Србије, на основу потписаног Уговора о реализацији и финансирању НИО у 2020. години, као и Плана рада НИО Факултета безбедности за 2020. годину

2 Аутор је руководилац Аналитичког центра ЕсооМ и члан научноекспертске групе при Државном секретаријату Совета безбедности Републике Белорусије. e-mail: ecoom@gmail.com
} 


\section{УВод}

Пре више од два и по миленијума Питак, један од седам древних грчких мудраца, тиранин на Лезбосу, говорио је: „Посао паметних је да предвиде невољу пре него што она дође, а посао храбрих је да се носе са невољом када се она догоди.“ Ситуација са ковидом 19 била је у таквом замаху да је условила одлуку Светске здравствене организације којом је 11. марта 2020. године прогласила пандемију. Вирус је у већој или мањој мери почео да се шири и погађа све континенте. У условима неадекватног деловања власти и нарочито средстава јавног информисања, пандемија је значајно повећала страх код људи по сопствени опстанак и судбину чланова породице, локалне заједнице и друштва у целини. На тај начин голи опстанак у кратком року постаје главни интерес, гурајући у страну појединачна права, па чак и националну солидарност.

\section{ПАНДЕМИЈА И АНТИПАНДЕМИЈСКА РЕАКЦИЈА}

Ширење коронавируса открило је бројне проблеме који су латентно чекали праву прилику. Живот великих градова и градских подручја постао је парализован за неколико дана, што је угрозило добробит милиона људи, посебно оних чији приходи критично зависе од услужне економије, типичне за постиндустријски

град. Светска здравствена организација је била на удару најразличитијих критичара, а Сједињене Државе, као највећи финансијер ове организације, престале су да дају средства за њен рад. Европска унија (ЕУ) је такође испољила низ слабости као интеграционо удружење. Због затварања многих граница Шенген није функционисао, односи унутар савеза су бивали све напетији, а захтеви за помоћ земаља јужне Европе (Италије и Шпаније) нису наишли на очекивани одзив.

Стручњаци ће дуго анализирати зашто су се неке земље успешније од других опирале ширењу вируса и у којој мери ће донете мере утицати на економију, погођену рестрикцијама. Бројни ауторитарни лидери настојали су да сакрију размере катастрофе и занемаре последице пандемије. Било је и неефикасних покушаја да се уведу оштре, али непромишљене мере за контролу кретања грађана, као и самоуверених одговора појединих влада на кризу. Нецелисходност националног здравственог система (то нису само сиромашне земље Трећег света, већ и Сједињене Државе и многе друге), или његово значајно урушавање (као у Италији, нпр) и огромни трошкови који су морали хитно да се исплате погоршали су ионако тешку привредну ситуацију.

Значај традиције, културе и менталитета за функционисање једне политичке заједнице веома јасно се испољио у борби против ковида 19. Евидентно је да су нпр. Кинези и Корејанци показали високо ефикасан приступ, док су Сједињене Државе примениле хаотичну политику задржавања, која се претворила у катастрофу. Уочене разлике објашњавају се социо-културним факторима. Темељне вредности друштва, његова традиција и култура морају бити у сагласности са политичким поретком, сматра знаменити француски политички 
мислилац Монтескје (Charles Montesquieu). За њега, као и за Аристотела, не постоји најбоља политичка заједница. „Друга најбоља заједница“ је умерени и уравнотежени политички поредак који садржи различите политичке принципе и који почива на сагласности са карактеристикама народа у чијем интересу је успостављен. „На законодавцу је да следи дух нације када он није опречан начелима владавине, јер ништа не чинимо боље него када поступамо слободно и следећи свој природни гениј“(Монтескје). ${ }^{3}$

У оквиру упоредне анализе реакције политичких система на пандемију угрубо се могу уопштити три основна модела политичког понашања. Први је источноазијски (кинески) модел. Он је карактеристичан по томе што политичка елита доноси одлуке, не осврћући се посебно на мишљења и ставове становништва, али уз ослонац на научну експертизу. Људи у источној Азији, без обзира на политички систем, социјално су дисциплиновани и спремни да се придржавају мера ограничења које власт прописује. У средишту другог модела је личност свезнајућег и свемоћног политичара, који углавном због свог одлучног и харизматичног понашања настоји да убеди људе да све држи под контролом. Овај приступ се могао уочити не само у државама са ауторитарним традицијама. У оквиру тог модела било је и нарушавања уставних и законских одредаба „у име општег добра“. Коначно, трећи начин деловања карактеристичан је за либералнодемократске уставне системе. Тамошњи политички курс заснован је на препорукама стручњака, као и на разним очекивањима и обавезама које власти морају да испуне. За његову примену неопходна је подршка становништва која захтева детаљно објашњење одређених мера. Грађани прво морају да се увере у неопходност одговарајућег понашања, па тек онда могу да га прихвате.

На индивидуалном нивоу, према социолошким истраживањима, у западним друштвима широко је распрострањена идеологија „одговорности“, боље речено пребацивање одговорности за сопствени живот (укључујући пратеће ризике) на саме појединце. И премда су критичари више пута скретали пажњу на улогу структурних фактора у формирању стварних животних могућности људи, идеологија „одговорности“ успешно се социјализовала у савременом западном друштву и постаје све мање проблематизована у политичком и у друштвеном дискурсу4. У оквиру сваке од ових група постоје варијације и специфичности везане за конкретну средину и њене посебности.

Борба против глобалне вирусне инфекције карактерише се између осталог и тиме што је уздрмала и ставила под сумњу многе до тада неприкосновене „светиње“ и табуе. Појавиле су се сумње којих раније није било. Прва је везана за снагу

3 Цитирано према: Мирослав Младеновић, „Политичка култура и 'грађанска врлина'“ у савременом политичком поретку“, Годишњак Факултета безбедности, Vol. 12, 2012., стр.125-134.

4 Видети шире у: Лика Родин, „Пандемия Ковид-19 и пределы неолиберального подхода“, Центр политического анализа, 24.2020 , https://centerforpoliticsanalysis.ru/position/read/id/pandemija-kovid-19-i-predelyneoliberalnogo-podhoda, 16/09/2020. 
„демократије“5 у сложеним друштвеним условима. Још је Макијавели упозоравао да природа режима зависи од околности, политичке културе грађана и вештине управљача. Он због тога није давао предност ни републици ни монархији. У принципу, формирање републике примереније је мирним временима, а монархије - неповољнијим и изнуђеним приликама ${ }^{6}$. Друга се тиче отпорности међународних организација на непредвиђене ударе. Европска унија је испољила низ слабости као интеграционо удружење. Због затварања многих граница Шенген није функционисао. Односи унутар савеза су почели да се ремете, а захтеви за помоћ од стране појединих земаља су блокирани. Трећа карактеристика је олако посезање за слободама и правима грађана. Испоставило се да кадгод не постоји право решење, најједноставније је увести рестрикције. Већина одлука које су се наметале ишла је у правцу сужавања прокламованих демократских обележја, чак и најразвијенијих друштава, у корист успостављања форми деловања карактеристичним за мање слободне заједнице.

„То није чудно“, каже Меша Селимовић у Тврђави, јер је лакше „наговорити људе на зло и мржњу него на добро и љубав. Зло је привлачно и ближе је људској природи. За добро и љубав треба израсти, треба се помучити“7. Можда је то последица и историјске младости људске цивилизације, јер, како истиче Карл Густав Јунг: „човек је само релативно мало хиљада година провео у култивисаном стању, а многе стотине хиљада година у некултивисаном“".

\section{Алтернативни приступ пандемији: Белорусија}

Реакције већине земаља биле су сличне и углавном осмишљене споља. Нешто другачији приступ имале су од европских земаља Шведска и Белорусија. Заједничко за обе земље је неприхватање препорука СЗО, односно настојање да се мере заштите од болести организују превасходно полазећи од сопствених, конкретних услова и могућности. За разлику од остатка Европе, ове земље су одустале од строгих општих мера. Ипак, и код њих реакција није била идентична.

На почетку кризе Шведска је активно узела учешћа у процесима доношења антипандемијских мера на нивоу ЕУ. Чак је у ту сврху донирала 40 милиона круна у кризни фонд СЗО. Међутим, унутар земље однос према епидемиолошким изазовима одликовао се фрагментарношћу и приметним контрадикцијама. То се

5 Појам „демократија“ стављен је под наводнике из простог разлога што га је неопходно дефинисати пре употребе. С обзиром на потребе овог рада, овде ће се под „демократијом“ подразумевати уобичајени (идеолошки) садржај везан за карактеристике западних либералних друштава.

6 Мирослав Младеновић, „Политичка култура и 'грађанска врлина' у савременом политичком поретку“, op. cit.

7 Меша Селимовић, Тврђава, Отокар Кершовани и Слобода, Ријека и Београд, 1975, стр. 225.

8 Карл Густав Јунг, према: Есад Ћимић, Политика као судбина, Младост, Београд, 1981, стр. 166. 
пре свега испољило дијаметрално различитим проценама природе и обима проблема, назначеним приоритетима деловања, као и нејасном одговорношћу и компетенцијама за доношење одлука. Неопходност противепидемијских мера, стање здравственог система, али и економски проблеми били су главне непознанице већине држава, па тако и Краљевине Шведске. У настојању да се та три проблема реше истовремено и без занемаривања било којег од њих, шведски модел се карактерисао сопственим, а не препорученим реакцијама и решењима. У даљем тексту више речи биће о Белорусији, с обзиром да је реч о бившој социјалистичкој земљи и држави која настоји да очува релативну независност.

Белорусија, као ни Шведска, није применила строги карантин. Једноставно, пошло се од конкретних услова и могућности и деловало у складу са сопственим проценама и потребама. Полазиште је било да могућност опоравка и уопште реакција на вирус умногоме зависи од човековог здравља, имунитета и животног стила и да ти показатељи нису исти у свим регионима и државама. Како је дошло до тога да ова земља реагује на пандемију различито од огромне већине других држава? Белорусија је и раније имала слична искуства са другим инфективним болестима, из чега су извучени ваљани и трајни закључци. Такође, после распада СССР-а, Белорусија није (као остале бивше чланице) похрлила да забрањује вакцине, ликвидира мале домове здравља и уништава систем инфективних болница. Држава се није укључила у некритичку и превасходно идеолошку кампању - „НЕ совјетском наслеђу“. Аналитички је сагледано шта је то што је добро и што треба и даље неговати, а шта заменити неким новим решењима. Белоруски здравствени систем, захваљујући задржаној основи и нормативима који су били добри у СССР-у, бележи у тој области значајно позитивније резултате у односу на оне који су се нихилистички понели према наслеђу бивше заједничке државе.

На тај начин, основу процена у Белорусији чинили су: сачувано совјетско искуство, реално стање здравственог система, мишљења сопствених лекара и информације добијене на основу стране, превасходно кинеске праксе. Приоритет се састојао у изолацији људи из ризичних група (старији и они који пате од хроничних болести), као и обезбеђивање заштите медицинским радницима. Идеја је била да се пандемија „развуче“ без преоптерећења здравственог система, као и да се формира колективни имунитет, у којем коронавирус више неће представљати озбиљну опасност. Процењено је да би строге мере, поред економских и других последица, чак и у здравственом смислу изазвале компликације, јер би после неминовног попуштања евентуално уведеног карантина неизоставно наишао нови удар. Почетком марта успостављен је специјалан информативни званични канал „Минздравбеларус“. На њему су оперативно провођене прес-конференције и емитоване новости везане за епидемију. За разлику од већине других информативних система у свету, остали канали радили су у уобичајеном режиму.

У Белорусији држава и даље игра водећу улогу у финансирању трошкова здравствене заштите. Укупни износ потрошње на здравство у 2017. години износио је 6,0\% БДП-а државе, од чега је потрошња у јавном сектору - 4,2\%, а у 
приватном сектору - 1,8\% БДП-а 9 . Након ликвидације СССР-а значајно је развијана сопствена производњу лекова, што је сигурно помогло земљи да се квалитетно носи и са последицама ковида 19. Ова чињеница је посебно дошла до изражаја у условима када су многе земље током карантинских мера ограничавале или заустављале испоруку лекова. У белоруском здравственом сектору ради више од 300 хиљада људи. Само у августу 2019. године више од 9 хиљада младих специјалиста дошло је у клинике и болнице у земљи.

Један од кључних показатеља квалитета здравственог система и квалитета живота уопште јесте смртност деце. Врхунац је био 1990. године - 12,46 смрти деце млађе од једне године на хиљаду рођених. До 2018. године та бројка се смањила на 3,03. Број умрлих, млађих од 7 дана (на хиљаду живорођених), 1990. године износио је 5.84. У 2018. години тај број се смањио на 0.710. У Белорусији је овај показатељ најнижи не само у Заједници Независних Држава већ је према новом истраживању Дечјег фонда Уједињених нација (УНИЦЕФ) један од најнижих на свету.

Графикон 1: Преглед смртности деце у земљама ЗНД11

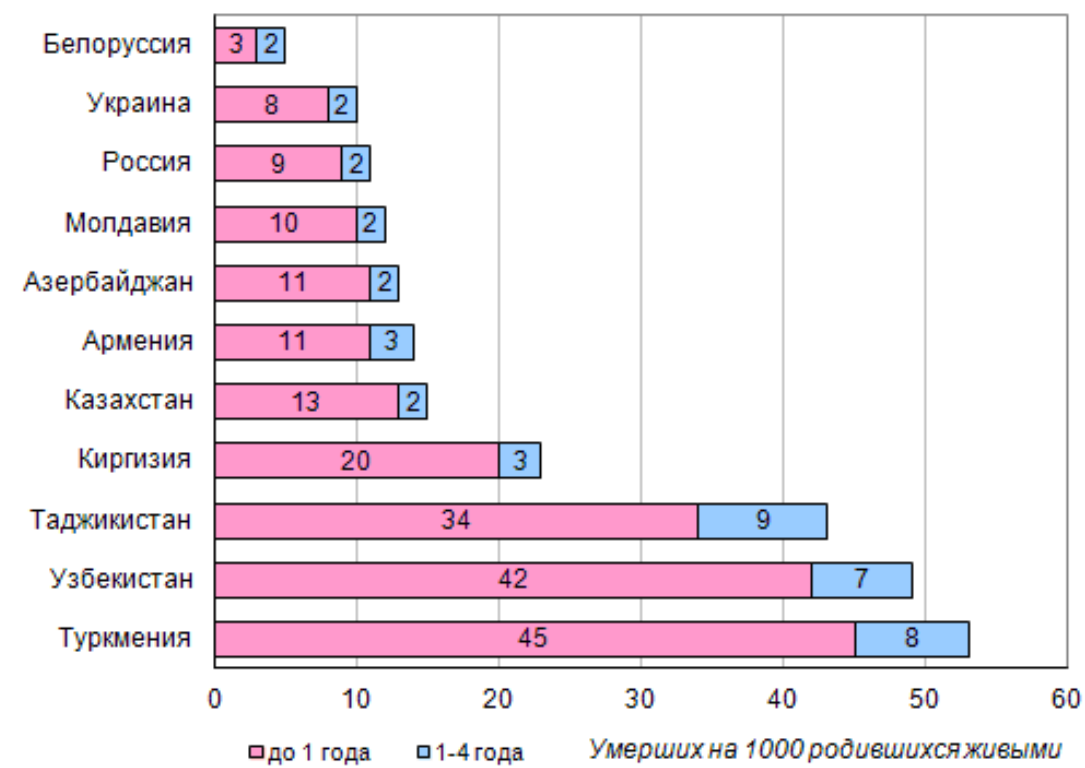

Све болнице у Минску имају универзитетске катедре, тако да се научнообразовни процес одвија у реалном практичном амбијенту. Резултат је смањење стопе смртности мајки у Белорусији са 38 на 100 хиљада рођене деце, колико је

9 „Расходы на здравоохранение в процентах от ВВП, 2017“, The Global Economy, https://ru.theglobaleconomy.com/rankings/Health_spending_as_percent_of_GDP/, 17/09/2020

10 Наталья Беницевич, „В 2019 году был самый низкий показатель младенческой смертности в истории Беларуси“, https://yandex.com/turbo/news.tut.by/s/society/673928.html, 17/09/2020.

11 Екатерина Щербакова, “Несмотря на снижение в 2005-2012 годы смертность в странах СНГ остается сравнительно высокой”, Демоскоп Weekly, No. 571-572, 2013, pp. 1-29, http://www.demoscope.ru/weekly/2013/0571/barometer571.pdf, 17/09/2020. 
било 1991. године, на само - 412. Захваљујући ефикасном систему посматрања и лечења Белорусија је међу десет европских земаља са највећом стопом преживљавања деце са хематолошко-онколошким болестима - преко 75\%. Лекови за децу, нутриционистичка терапија за њих и труднице су бесплатни, као и тестови за ковид 19.

Задатак здравственог система у Белорусији почетком пандемије био је да спречи лавину, односно ударни талас болести, што је била видна карактеристика у многим земљама. Полазећи од сопствене процене, пролећни школски празници за децу су продужени. Министарство здравља затражило је од цркава да богослужење спроводе на отвореном и да се придржавају санитарних стандарда. Међутим, храмови у Белорусији нису били затворени од самог почетка заразе. Између осталог, организовано је онлајн емитовање црквених служби. Министарство здравља је 10. априла 2020. године дозволило контактима првог нивоа да се самоизолују код куће (до 14 дана), уз издавање потврде о неспособности за рад. За те људе организован је медицински надзор код куће и свакодневне телефонске консултације. Ради размене искустава и давања важних упутстава уведена је интерна ТВ комуникација лекара из окружних и сеоских болница са најбољим лекарима у земљи. У складу са уредбом Министарства здравља од 1. јула 2020. године издате су привремене препоруке о организацији медицинске неге пацијената са инфекцијом ковид 19. Препоруке су урађене на основу сопственог искуства у погледу дијагнозе, пружања медицинске неге, лечења и усмеравања пацијентима са инфекцијом, узимајући у обзир и препоруке C30, стране научне публикације и материјале. Такав документ је изузетно недостајао целом свету и сви су чекали препоруке од С30.

По питању опремљености за лечење респираторних болести Белорусија је испред многих већих и развијенијих држава. На 100 хиљада људи држава располаже са 22 уређаја за вештачку вентилацију плућа. Ако томе додамо и анестезионодисајне апарате, онда на 100 хиљада становника дође 38 уређаја. Поређења ради, тај број у

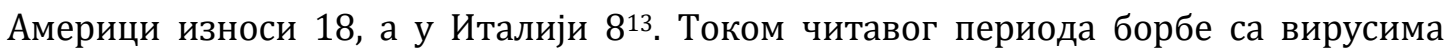
коришћено је највише 25 апарата истовремено, што је око 10\% њиховог укупног броја. Ради сагледавања стварних показатеља „учинка“ ковида 19 најбоље је упоредити податке о броју умрлих у истом периоду ранијих година. Према извештају Белоруског националног статистичког комитета, број умрлих од респираторних болести у периоду јануар - март 2020. године чини 80\% у односу на исти период претходне године. Од јануара до марта 2019. године од свих врста упале плућа у Белорусији је умрло 277 људи, а у истом периоду 2020. године - 254.14

12 Ibid.

13 Элешевич, Мария, „В Беларуси 22 аппарата искусственной вентиляции легких на 100 тысяч человек, в США - 18, в Италии - 8,3". Минздрав отчитался о количестве аппаратов ИВЛ“, Комсомольская правда, 23. март 2020, https://www.kp.by/online/news/3807168/, $17 / 09 / 2020$.

14 Белоруски национални статистички комитет, https://www.belstat.gov.by/, 17/09/2020. 


\title{
СРЕДСТВА ЈАВНОГ ИНФОРМИСАЊА У УСЛОВИМА ПАНДЕМИЈЕ
}

У оквиру анализе опште ситуације око пандемије посебно место припада улози средстава јавног информисања. Од раније је евидентно да се глобализација у области медија испољава кроз уједначавање мишљења и укуса путем избора и унифицирања информација. Медијском централизацијом политички центри моћи непосредно утичу на пласирање жељених информација и тако дизајнирају свакодневицу према одређеном моделу. Пет највећих светских медијских групација „Велика петорка“ тренутно држи више од половине свих медија на планети. Свих пет групација поседују филмске, телевизијске, радијске, издавачке и новинске куће и пружају интернет услуге. То значи да покривају све видове јавног информисања, на свим континентима и у свим земљама света. 15

Карактеристично је да су се у условима пандемије поред централних значајно активирали и локални медији. Општа оцена је велики број дезинформација, пласирање непроверених вести и, што је најгоре, негативан утицај на морал и опште стање становништва. Нису изостали ни „савети“ за излечење са крајње сумњивим и непровереним лековима. Ако погледамо основне традиционалне функције медија (информативна, едукативна, забавна), ниједна није у потребној мери реализована. Према уреднику агенције Fake News, Стефану Јањићу:

\begin{abstract}
„Читав свет је сада фокусиран на једну једину тему, па се у вези са њом покреће читав низ лажних вести, теорија завере, псеудонаучних процена и савета. Бесмислице се преливају из једне државе у другу, преводе се и надограђују, а чак и ако их главни медији не пренесу остају друштвене мреже као инкубатор“.16
\end{abstract}

Разуме се, новинар не може бити и стручњак за вирусологију, али оно што је у његовој природи посла, то је правилан избор извора информација и провера поузданости тих извора. „Свако треба да ради свој посао професионално и одговорно. Хаос и паника настају када имамо гомилу опречних и/или непроверених информација, када државни врх један дан каже да ситуација није страшна, после пар дана изађу и кажу да је много озбиљно, када новинари објављују како је нађен лек за корону и упуте људе на тај хлорокин или било који други лек, па онда у другом тексту изнесу неке најцрње прогнозе, како ће пола

15 Зоран Килибарда, Мирослав Младеновић, Владимир Ајзенхамер, Геополитичке перспективе савременог света, Факултет безбедности, Београд, 2014, стр. 213.

16 Наталија Јаковљевић, „Medijski stručnjaci tokom pandemije: Poverenje građana u novinare, lekare i struku na velikom testu“, Цензоловка, 1. април 2020.

https://www.cenzolovka.rs/etika/medijski-strucnjaci-tokom-pandemije-poverenjegradjana-u-novinare-lekare-i-struku-na-velikom-testu/, 18/09/2020, 
планете помрети итд... То су ситуације у којима се људи потпуно погубе и не знају ни шта да раде ни коме да верују“17.

\section{ПОЛИТИЧКЕ ПОСЛЕДИЦЕ ПАНДЕМИЈЕ КОВИДА 19}

Пре или касније, пандемија ће се завршити и све државе ће морати да се суоче са њеним последицама. Како то може да се манифестује у сфери политике? „Свет више никада неће бити исти“ - чујемо на сваком кораку. Овој изјави се често додају различита апокалиптична предвиђања, чији аутори плаше друге и себе очекивањима од страхота које ће уследити након пандемије, од тријумфа универзалног и потпуног дигиталног тоталитаризма до масовног изумирања појединих професија које ће заменити онлајн институције. Ипак, мора се направити разлика између онога што је резултат тренутне ситуације и појава које су фундаменталне природе. Било је, наравно, догађаја у историји на основу којих је живот почео да се дели на „пре“ и „после“. Такви догађаји су били, на пример, револуција у Русији 1917. године, долазак на власт нациста у Немачкој 1933. године, рушење Берлинског зида, распад Варшавског уговора и сл. Данашњи догађаји немају такав карактер. Они нигде у свету нису довели до покушаја револуције или уништења основних институција.

У другој групи предвиђања преовлађује схватање да ће се неке промене неизоставно догодити, али оне неће бити у области политичке организације друштва. После терористичких напада на авионе људи су пристали на инспекције на аеродромима, забрану превоза течности и многе друге захтеве, раније непознате. Свакако ће се и на основу резултата актуелних догађаја у здравству извршити структурне и друге промене, а људи ће усвојити нека нова хигијенска правила (одустајање од традиције љубљења при сусрету, чак и руковања, побољшање хигијене руку и слично). Што се тиче политичких релација, оне ће остати углавном исте.

У Сједињеним Државама већ иде предизборна кампања и сигурно се неће угрозити приватно власништво, као и основне политичке институције које тамо постоје. Кина услед пандемије неће увести западне демократске облике организације власти. У Русији ће се понашање власти и опозиције проводити у оквиру претходних парадигми. Наравно, неадекватни поступци или нечињење руководства знатно су смањили рејтинг појединих политичких личности и повећали критику система, али револуционарна ситуација није достигнута, осим што неке, чак и врло важне особе могу заменити друге.

Трећа група анализа доводи до закључка да ће свет бити фрагментиранији и да ће доћи до извесног отклона ка аутократизму и антиглобализму. Упоредо с тим, како показују прорачуни експертске групе ОУН (UN DESA), становништво земаља тренутног глобалног центра (Северна Америка и САД) неће расти, док ће се

17 Ibid. 
истовремено у земљама Азије и Африке значајно повећавати број становника током наредних двадесетак година. Тиме се може очекивати демографски притисак на западне земље, што реално може ојачати тенденцију ка „незападњаштву“ и растућу улогу земаља са мањкавом демократијом или аутократијом ${ }^{18}$.

Да ли ће се интензивирати демократија или ће се свет вратити ауторитарности? У почетку се чинило да диктатурама иде боље, односно, што више слободе, то више хаоса и жртава. Међутим, касније се ситуација заокренула у другом смеру, изражена пре свега кроз успех Немачке и нејасне ситуације у вези са Кином и Русијом. У сваком случају, пандемија је највећи тест снаге и ефикасности и демократије и диктатуре од Другог светског рата до данас. Масовни губици посла могу да створе социјалне проблеме у великим градовима и знатно погоршање криминалне ситуације. Све то отвара суштински нове изазове за стручну заједницу - урбанисте, стратеге на пољу економске политике, праксе урбаног управљања, безбедности итд.

Путеви прилагођавања новом окружењу, како међу демократијама тако и међу аутократијама, вероватно ће показати прилично јаке варијације, углавном због разлика у природи изазова са којима се суочавају. Чињеница је да стручњаци тешко успевају да прецизно предвиде будућност. Може се претпоставити да се политика у свету неће променити до непрепознатљивости. Владе ће, свака на свој начин и у својим околностима, морати да реше оне проблеме који се нису од јуче, већ су само изашли у први план као резултат актуелне кризе.

\section{ПОСТПАНДЕМИЈСКА ГЕОПОЛИТИКА}

По мишљењу једне групе теоретичара пандемија није срушила стари свет нити је променила његове приоритете. Суштински, она је била само катализатор за оне процесе који су већ били у току, убрзала их је и учинила експлицитнијима. Попут земљотреса, коронавирус је уништио само нестабилне структуре, чак и оне чија је фасада изгледала чврсто и привлачно. Други сматрају да је свет постао фрагментиранији. Иако је старо веровање да различите људе и системе најбоље окупља заједнички непријатељ, корона то није учинила. Испоставило се да су национални егоизми јачи. Светски систем је постао много фрагментиранији. Антиглобализацијски процеси, који су одувек, у већој или мањој мери, били присутни у свим земљама, као да су добили нови замајац. Пандемија је убрзала тенденције враћања у сопствене државне љуштуре. Протекционизам, различити видови санкција, манипулација валутама, ограничење миграције, подршка

18 Видети шире у: Михаил Минаков, „Пандемия COVID-19 и политические очертания будущего“, Европейский диалог,

http://www.eedialog.org/ru/2020/05/22/pandemija-covid-19-i-politicheskie-ochertanijabudushhego/, 18/09/2020. 
сопствених произвођача итд. - све што је пре епидемије имало тенденцију пораста, сада је враћено у матично корито.

Важно обележје опште слике изазване пандемијом јесте пораст националних егоизама, затварање граница, непостојаност здравствених система и ограничавање слобода и права грађана. Све ово значајно оштећује слику Запада као носиоца идеје друштва будућности, на коју би други требало да се угледају. То је веома озбиљно уздрмало западни идеолошки модел који се много година стварао и наметао.

На глобалном плану главни ривали ће највероватније бити Кина и САД. Моћ Америке, која је и иначе била у паду, вероватније ће још брже наставити тај тренд, пре свега гледано кроз економске параметре, којима је пандемија значајно допринела. Процене су да Кина неће имати такве економске последице и да ће темпо њеног опоравка, па и јачања, бити знатно већи. У борби за светско лидерство Русија ће највероватније имати другостепену улогу, али ће њена позиција више одговарати Кини него Америци. Може се рећи да Кина представља '“природног историјског“ савезника Русије, с обзиром да њени интереси, за разлику од америчких, очигледно не противрече руским. НРК се не меша у унутрашње ствари Руске Федерације, не инсталира своју агентуру у руску елиту, не врши идеолошку обраду руске омладине и руског јавног мњења. На крају, и Русија и Кина су заинтересоване за структурно јачање државе као главног носиоца сопствене цивилизације, у то време кад САД на дугорочном плану воде политику демонтаже државе (туђе) као елемента структуре будућег света који ће бити формиран у оквиру новог универзалног система под америчким руководством ${ }^{19}$. Процене су да САД свакако неће „без борбе“ препустити позицију светског лидера.

Кина неће моћи да избегне конфронтацију коју ће Америка иницирати. Кинеска стратешка култура поставља другачије основе за деловање, и циљ Кинеза није глобална хегемонија у класичном смислу. Што се тог сукоба тиче, Кина делује отпорније. Има жилавију економију и бољу демографску ситуацију. Има реалних изгледа да врло брзо поново достигне позитивне економске билансе. Истина, Пекинг је слабији у компоненти стратешког офанзивног наоружања, али је мало вероватно да ће доћи до потребе његовог ангажовања.

\section{ЗАКЉУЧАК}

Пандемија и противепидемијске мере показале су да је ефикасност рада националних влада често ниска. Корупција, недостатак професионалности званичника и политичара и последице неолибералних реформи јавног здравља показују да је живот у локалним заједницама недовољно осигуран и рањив у

19 Видети шире у: Мирослав, Младеновић и Јелена, Пономарева, „Кина - Америка - Русија глобални троугао 21. века“ Социолошки преглед, вол. 45, бр. 4, 2011, стр. 459-476. 
многим сегментима. Таква сазнања допринела су ситуацији „незападности“. То је стање у коме модел западних земаља губи функцију глобалног центра и доводи до померања геоекономског и геополитичког тежишта са либералнодемократског Запада на ауторитарни Исток.

Политичка и правна аутаркија националне државе, која се у неким случајевима јарко испољавала и пре пандемије (Путинова Русија, Орбанова Мађарска, Ердоганова Турска, Трампове САД), кроз евидентан нелиберални тренд, очигледно добија знатно веће могућности у постпандемијској глобалности. Посебан проблем ће свакако бити везан за испољене манифестације економске кризе повезане са порастом незапослености. Чињеница је да је највише због тога ниво подршке одређеном броју лидера значајно промењен (у једну или другу страну). Због тога се може очекивати да наредни (а понегде и ванредни) избори у многим демократијама за собом повуку и промену руководства.

\section{ЛИТЕРАТУРА}

1. Ћимић, Есад. Политика као судбина, Младост, Београд, 1981.

2. Килибарда, Зоран, Младеновић, Мирослав, Ајзенхамер, Владимир. Геополитичке перспективе савременог света. Факултет безбедности, Београд, 2014.

3. Элешевич, Мария, „В Беларуси 22 аппарата искусственной вентиляции легких на 100 тысяч человек, в США - 18, в Италии - 8,3". Минздрав отчитался о количестве аппаратов ИВЛ“, Комсомольская правда, 23. март 2020, https://www.kp.by/online/news/3807168/, 17/09/2020.

4. Родин, Лика. „Пандемия Ковид-19 и пределы неолиберального подхода“, Центр политическогонализа, 24. март 2020. https://centerforpoliticsanalysis.ru/position/read/id/pandemija-kovid-19-ipredely-neoliberalnogo-podhoda, 16/09/2020

5. Селимовић, Меша. Тврђава. Отокар Кершовани и Слобода, Ријека и Београд, 1975.

6. Младеновић, Мирослав. „Политичка култура и 'грађанска врлина' у савременом политичком поретку“, Годишњак Факултета безбедности, Vol. 12, 2012, стр. 125-134.

7. Младеновић, Мирослав и Пономарева, Јелена. „Кина - Америка - Русија глобални троугао 21. века." Социолошки преглед, вол. 45, бр. 4, 2011, стр. 459-476.

8. Минаков, Михаил. „Пандемия COVID-19 и политические очертания будущего“, Европейский диалог, http://www.eedialog.org/ru/2020/05/22/pandemija-covid19-i-politicheskie-ochertanija-budushhego/, 18/09/2020.

9. Јаковљевић, Наталија. „Medijski stručnjaci tokom pandemije: Poverenje građana u novinare, lekare i struku na velikom testu“, Цензоловка, 1. април 2020. https://www.cenzolovka.rs/etika/medijski-strucnjaci-tokom-pandemije-poverenjegradjana-u-novinare-lekare-i-struku-na-velikom-testu/, 18/09/2020, 
10. "Расходы на здравоохранение в процентах от ВВП, 2017", The Global Economy, https://ru.theglobaleconomy.com/rankings/Health_spending_as_percent_of_GDP/, $17 / 09 / 2020$.

11. Беницевич, Наталья. „В 2019 году был самый низкий показатель младенческой смертности в истории Беларуси“, Tut. by, https://yandex.com/turbo/news.tut.by/s/society/673928.html, 17/09/2020.

12. Щербакова, Екатерина. "Несмотря на снижение в 2005-2012. годы смертность в странах СНГ остается сравнительно высокой”, Демоскоп Weekly, No. 571-572, 2013, pp. 1-29, http://www.demoscope.ru/weekly/2013/0571/barometer571.pdf, $17 / 09 / 2020$.

\title{
A POLITICAL SCIENCE ANALYSIS OF DIFFERENT RESPONSES TO COVID-19 PANDEMIC
}

\begin{abstract}
The global problem which we read about in science fiction books became a reality. It seems that numerous artistic creations and films on this topic became either prophetic or have served as a blueprint for practical action. What appeared in reality, as well as its consequences, is able to outmatch fiction. The informative influence, inspired by diseases is without precedent in the world. Global security issues are obvious. In spite of the pandemic, announced by the World Health Organization (WHO), no armed conflict in the world has ceased. It turned out that the "commander and chief of Earths rapid reaction forces" - WHO was to a large extent unprepared, as were the majority of states in the world. The combat tactics to counter the pandemic are changing from time to time and from state to state, with constant accusations towards one another. Many world leaders have demonstrated themselves as being the leaders of incompetence. It still has not been fully clarified where exactly did the distribution of COVID-19 begin, as well as its true origins. In this paper we will strive to conduct a political science analysis of functioning of states in the conditions of threats to their security systems by comparing states which introduced strict pandemic and quarantine measures and alternative behavior of Belarus and Sweden.
\end{abstract}

Key words: COVID-19, pandemic, Belarus, WHO, political changes 